Т. В. Мелкумова

\title{
ФУНКЦІОНАЛЬНЕ ПРИЗНАЧЕННЯ АНТИПОФОРИ В ІНФОРМАЦІЙНОМУ МОВЛЕННІ
}

Мелкумова Т. В. Функціональне призначення антипофори в інформаційному мовленні.

У статті розкрито комунікативно-прагматичні функції антипофори (риторичної фігури - запитання й відповідь). 3'ясовуються особливості та доречність використання антипофори у власне інформаційних і коментарних текстах.

Ключові слова: антипофора, комунікативно-прагматичні функції, власне інформаційний текст, коментарне мовлення. 
Мелкумова Т. В. Функциональное назначение антипофоры в информационной речи.

В статье раскрываются коммуникативно-прагматические функции антипофоры (риторической фигуры - вопрос и ответ). Выясняются особенности и уместность использования антипофоры всобственно информационных и комментарных текстах.

Ключевые слова: антипофора, коммуникативно-прагматические функции, собственно информационный текст, комментарная речь.

Melkumova T. V. The functional purpose of the antipophora in the information speech.

The article presents the communicative-pragmatic functions of the antipophora (the rhetorical figure - the question and the answer). The peculiarities and appropriation of the usage of antipophora in the information texts proper and the texts based on the commentaries are also determined here.

Key words: antipophora, communicative-pragmatic functions, information texts proper, speech based on the commentaries.

Антипофора (запитання й відповідь, вопросно-ответный ход - рос.) $\epsilon$ однією 3 риторичних фігур. Риторичні фігури - це особлива група стилістичних фігур, виразність яких заснована на їхньому умовнодіалогічному характері. Основними риторичними фігурами, окрім антипофори, є заперечення, звертання, питання, ствердження, вигук, оклик.

Антипофора діалогізує монологічне мовлення, перетворює адресата на співрозмовника мовця, активізує його увагу. Діалогізація оживлює та увиразнює розповідь [4]. О. Д. Пономарів зазначає, що фігура «питання й відповідь» використовується для загострення уваги на певному понятті [5, с. 241]. Сегментуючи мовлення, пише Н. М. Івакіна, ця риторична фігура надає мовленню експресивності, відтінку безпосередності [2, с. 145]. Антипофора, на переконання О. П. Сковородникова, полегшує й активізує сприйняття мовлення слухачем i, надаючи текстові розмовності, допомагає встановити більш тісний контакт з адресатом [6, с. 83].

Попри свою поширеність у всіх функціональних стилях, антипофора $\epsilon$ мало дослідженою сучасним мовознавством риторичною фігурою. Більшість посібників із риторики, літературознавства, стилістичного синтаксису неправомірно уникають тлумачення антипофори, яка $\epsilon$ частим засобом увиразнення мовлення будь-якого функціонального призначення.

Ti науковці, що звертаються до характеристики антипофори, відзначають значну роль цієї риторичної фігури в організації судових промов (юридичне мовлення) [2]. Для судового мовлення діалогізація $\epsilon$ його внутрішньою якістю, пов'язаною 3 його функціональним призначенням - переконанням. Юристи вважають фігуру «запитання й відповідь» одним з основних засобів діалогізації, яка $\epsilon$ ознакою судового красномовства [3, с. 20-29].

Дослідження використання антипофори у творчості майстрів художнього слова обмежене поодинокими працями, при цьому антипофора розглядається стисло на тлі інших риторичних фігур або засобів 
діалогізації монологічного мовлення [1; 7]. Попри значний потенціал антипофори в увиразненні мовлення, відсутні присвячені лише цій риторичній фігурі дослідження, а також цілком відсутні відомості про використання антипофори в інформаційному, публіцистичному, розмовнопобутовому мовленні.

У нашій статті ми розглянемо використання антипофори в інформаційному мовленні. За мету приймаємо визначити комунікативнопрагматичні функції цієї риторичної фігури. Спробуємо з'ясувати особливості та доречність використання антипофори у власне інформаційних (ІПС) і коментарних (КПС) текстах.

Антипофора $\epsilon$ потужним засобом впливу на свідомість адресата. Ця риторична фігура здатна виконувати будь-яку комунікативно-прагматичну функцію, зокрема волюнтативну: Держава повинна регулювати ияі питання, ці проблеми? Звичайно, повинна [3. 23.12.2004] [КПС] - виділені предикати дії є виразниками директивного наказового інтенціонального значення наведеного мовленнєвого контексту. Антипофора увиразнюється ампліфікованими додатками (питання, проблеми) у питальній частині.

Синтаксична організація антипофори передбачає наявність, як правило, двох речень, різних за метою висловлювання. Це сприяє поліфункціональності стилістичної фігури - протягом нетривалого мовленнєвого уривка реалізуються кілька комунікативно-прагматичних функцій, посилюється прагматичний вплив мовлення: (1) A коли останній кидок [иін] був? (2) День у день збігається з приватизачією «Криворіжсталі». (3) А чому? (4) Тому щңо вона на другий день підняла иіни на відпускний метал на 600 гривень за тонну [3. 23.12.2004] [КПС]. Перша пара «запитання-відповідь» $(1 ; 2)$ реалізує власне репрезентативну функцію (пресупозиція: останній кидок цін був у день приватизації «Криворіжсталі»). Питання (3) виконує апелятивну функцію, запрошуючи адресата до роздумів, а відповідь (4) має експозитивне значення «пояснення повідомлення».

Власне репрезентативну, апелятивну та експозитивну функцію антипофора реалізує в такому контексті: (1) Що ж маємо сьогодні? (2) Страменний рейвах «нагорі» з вимогами здіснити реформу судової системи. (3) Не потрібно бути оракулом, щоб зрозуміти, задля чого ие робиться. (4) Задля того, аби всіх без винятку служителів Феміди зробити кишеньковими [УМ. 14.08.2003] [КПС]. Апелятивну функцію реалізують речення $(1,3)$. Власне репрезентативну функцію виконує речення-відповідь (2), а також речення (3) (пресупозиція: зрозуміло, задля чого це робиться). Експозитивну функцію реалізує речення (4).

У межах однієї надфразної єдності антипофора може реалізувати, наприклад, апелятивну, репрезентативну та оцінну функції: Ta чому, власне, потрібен закон про реприватизаџію? Тому щз чинний закон украй поганий [УМ. 14.08.2003] [КПС]. Ці ж функції реалізуються у такому 
контексті: (1) Ви думаєте, наприклад, грати роль телеведучого легше? (2) Зовсім ні, але я стараюсь робити ие щиро ц̆ професійно [ВП. 09.04.2009] [КПС]. Інтерпеляція (Ви думаєте) апелює до адресата, як і питання (1) загалом; мовець посилює увагу адресата до теми розмови. Репрезентативну функцію в реченні (2) реалізує головним чином його друга предикативна частина (мовець повідомляє: я стараюсь грати роль ведучого щииро й професійно). Проте й перша предикативна частина містить повідомлення із заперечувальною семантикою (нi, роль ведучого грати не легко). Ампліфіковані обставини ступеня якості (щиро й професійно) позитивно оцінюють власний досвід мовця в ролі телеведучого, сприяючи реалізації оцінної функції в реченні-відповіді (2).

Антипофора може мати таку схему функціонального навантаження: питання реалізує апелятивну функцію, відповідь - власне репрезентативну, наприклад: Де були в ией час державна акиіонерна компанія «Хліб України» $і$ Антимонопольний комітет? Бозна. Відомо лише одне: $y$ ситуаиію вони не втрутилися [УМ. 01.08.2003] [КПС].

Антипофора може сприяти виконанню висловлюванням експресивної та стверджувальної функцій: (1) Цікаво, а чи не виникало подібних поривів y наших міністрів? (2) Мабуть, ні [УМ. 12.08.2003] [КПС]. Питальне речення (1) реалізує експресивну функцію, оскільки мовець констатує свою зацікавленість. Відповідь (2) виконує стверджувальну функцію (ні, не виникало). Подібним чином реалізуються експресивна та стверджувальна функції в такому прикладі антипофори: Чи можливо було всі їx [42 питання] обговорити $i$ вирішити належним чином? Звичайно, ні [СС.Ч. 11.03.2005] [КПС].

Антипофора може виконувати актуалізаційну функцію. Прагматична мета «нагадування», що досягається використанням цієї фігури, посилюється анафоричним зачином питань (пам'ятаєте): (1) Пам'ятаєте, хто і як приймав цей закон? (2) Його провів Олександр Мороз. (3) А пам'ятаєте, чому цей закон прийняли? (4) Тому що прийшли вкрасти ваші голоси! [ВП. 01.10.2009] [КПС]. Речення-відповідь (4) у цьому риторичному діалозі мовця $\epsilon$ водночас реалізацією двох функцій експозитивної (пояснення повідомленого раніше) та оцінної (наміри політиків - злочинні).

В антипофорі можуть бути реалізовані апелятивна, експресивна, репрезентативна та експозитивна функції: (1) Хіба ж можливо наплювати на волевиявлення десятків тисяч вибориів $і$ викинути їхні голоси на смітник? (2) Виявляється, можливо - якщо ці голоси належать опозиційному кандидату... [В3. 11.11.2004] [ІПС]. Апелятивну функцію виконує питання (1), оскільки мовець прагне залучити читачів до діалогу, i неважливо, що відповідь не може бути ним почута, головне - аби спонукати адресатів до роздумів. Ампліфіковані дієслівні частини (наплювати, викинути) складеного головного члена допомагають мовцю 
виразити свій подив та обурення. Еліптична перша предикативна частина у відповіді (2) реалізує стверджувальну функцію (так, можливо наплювати на волевиявлення, можливо викинути голоси). Друга предикативна частина речення (2) виконує експозитивну функцію, пояснюючи, чому ж можливо так вчинити із волевиявленням виборців (якщо голоси належать опозииійному кандидату). Усічення надає читачам можливості поміркувати, спробувати віднайти власну відповідь, відчути свої емоції, можливо, відмінні від тих, що їх відчуває автор.

Вдалим вираженням оцінки в межах стилістичної фігури антипофори є реалізація оцінки не в частині-відповіді, а в питальній частині: (1) Марення психічно хворої людини? (2) Hi, читачу, це - російська фантастика - опус такого собі Григорія Савицького під назвою «Поле бою - Україна. Зламаний тризуб» [УМ. 28.02.2009] [ІПС]. У відповіді (2) експлікується повідомлюване значення: нi, це не марення; ие твір російського фантаста $<\ldots>$ (власне репрезентативна функція).

Антипофора часто взаємодіє 3 іншими стилістичними засобами, зокрема синтаксичними. Як наслідок - виразне та потужне в комунікативно-прагматичному аспекті мовлення. Наприклад, насичений стилістичними фігурами такий текстовий уривок: (1) Bu повірили, що заплатять гроші? (2) Так само, як повірили про тисячу гривень Ощзадбанку? (3) Повірили? (4) Повірили! (5) Повірили, щчо иукор буде 4 гривні? (6) I щзо? [ВП. 01.10.2009] [КПС]. Антипофора (3, 4), ампліфіковані риторичні питання, посилюваний повтор (повірили? так само, як повірили?), багаторазовий лексичний повтор (повірили - 5 разів) передусім сприяють реалізації експресивної функції (передача обурення та подиву мовця), а також посилювальної функції (переконаність мовця в тому, що народ більшою частиною повірив). Речення $(1,2,4,5)$ виконують стверджувальну функцію (наприклад (1): Так, повірили, що заплатять гроші). Риторичне питання (6) апелює до адресатів, пропонує зробити висновки, проаналізувати наслідки довірливості (апелятивна функція).

Взаємодіючи, антипофора та ампліфіковані риторичні питання реалізують експресивну та репрезентативну функції: (1) $A$ щзо ж тузла? (2) Як заявив заступник голови адміністраиії російського президента С. Приходько, «такої проблеми в російсько-українських відносинах не існує». (3) Так? (4) I давно? (5) А Президент Украӥни теж так вважає? [ДТ. 27.12.2003] [КПС]. Речення-відповідь (2) виконує репрезентативну функцію, переслідує прагматичну мету повідомити адресатам про точку зору діяча. Риторичні питання $(3,4,5)$ виражають подив мовця, його недовіру заяві, зробленій заступником голови адміністрації, сумнів, цікавість (чи обізнаний Президент з такою позицією російської сторони), тобто виконують експресивну функцію.

Отже, завдяки своїй побудові щонайменше з двох речень антипофора сприяє увиразненню інформаційного мовлення та посиленню його 
комунікативно-прагматичного функціонального впливу. Комунікативнопрагматичними функціями, що їх може реалізувати антипофора, $\epsilon$ такі: власне репрезентативна, волюнтативна, апелятивна, експозитивна, оцінна, стверджувальна, екпресивна, актуалізаційна, посилювальна. Виразність надфразної єдності, що містить антипофору, посилюється при взаємодії цієї риторичної фігури 3 іншими стилістичними засобами, зокрема синтаксичними (ампліфікацією, повтором, риторичним питанням тощо). Насичене стилістичними фігурами мовлення здатне до поліфункціональності, оскільки в межах одного мовленнєвого контексту реалізуються кілька комунікативно-прагматичних функцій.

Антипофора частіше увиразнює коментарні тексти, ніж власне інформаційні. Це пояснюється різною прагматичною метою текстів згаданих різновидів. Використання антипофори при коментуванні $\epsilon$ прагматично виправданим, оскільки коментарний текст покликаний не лише повідомити, а й роз'яснити інформацію, актуалізувати, надати оцінку тощо. Антипофора у власне інформаційних текстах, які повинні інформувати реципієнтів про події, може бути використана задля полегшення сприйняття мовлення адресатами, що $\epsilon$ важливою передумовою затримки уваги читачів на подальшій інформації. Дослідження антипофори в мовленні сучасних мас-медіа відкриває перспективи в поглибленні знань про тексти різного функціонального призначення.

\section{Література}

1. Гнатишина И. И. Внутренняя структура монолога (на материале произведений У. Шекспира): автореф. дис. ... канд. филолог. наук : спец. 10.02.04 «Германские языки» / Ирина Игоревна Гнатишина. - Санкт-Петербург, 2009. - 14 с.

2. Ивакина Н. Н. Основы судебного красноречия (риторика для юристов) : [учеб. пособие] / Надежда Николаевна Ивакина. - [2-е изд., перераб. и доп.] - М. : Юристь, 2006. - 455 с.

3. Лазарева В. А. Теория судебной речи : учеб. пособие / Валентина Александровна Лазарева. - Самара : Самарский университет, 2001. - 122. с.

4. Плещенко Т. П. Стилистика и культуры речи : учеб. пособие [для студентов филолог. специальностей высших учеб. заведений] / Т. П. Плещенко, Н. В. Федотова, Р. Г. Чечет; [ред. $\quad-\quad$ проф. П. П. Шуба]. $\quad$ - Мн. : «ТетраСистемс», 2001.- 544 с.

5. Пономарів О. Д. Стилістика сучасної української мови: підручник / Олександр Данилович Пономарів. - [3-тє вид., перероб. і доповн.]. - Тернопіль : Навчальна книга - Богдан, 2000. -248 с.

6. Сковородников А. П. Вопросно-ответный ход / Олександр Петрович Сковородников // Энциклопедический словарь-справочник. Выразительные средства русского языка и речевые ошибки и недочеты: справочное издание / [ред. - А. П. Сковородников]. - [2-е изд.] - М. : Флинта: Наука, 2009. - С. 83-85.

7. Соколова В. Художня функція риторичних фігур у поезії В. Свідзінського / Вікторія Соколова. - Слово і Час. - 2007. - № 11 (563). - С. 13-18. 
Перелік умовних скорочень використаних джерел

В3 - «Високий замок» - щоденна суспільно-політична газета

ВП - «Вісті Придніпров'я» - обласна газета

ДТ - «Дзеркало тижня» - міжнародний громадсько-політичний тижневик

3 - «Зоря» - Народна газета Дніпропетровщини

СС.Ч - «Свобода слова. Час 2000»- щотижневий буковинський часопис

УМ - «Україна молода» - щоденна інформаційно-політична газета

Стаття надійшла до редакиії 13.09.2010 p. 